\title{
RESIDUAL EFFECT OF PESTICIDES USED IN INTEGRATED APPLE PRODUCTION ON Chrysoperlaexterna (Hagen) (NEUROPTERA: CHRYSOPIDAE) LARVAE
}

\author{
Alexandre P. Moura ${ }^{1 *}$, Geraldo A. Carvalho ${ }^{2}$, and Marcos Botton ${ }^{3}$
}

\begin{abstract}
Temperate fruit crops are an important economic activity for growers in southern Brazil. However, several pest species are associated to apple (Malus domestica Borkh.) crops in Brazil. Pesticides are largely used to control them and one way to change this is to combine selective pesticides and predator insects. The goal of this research was to evaluate the effects of the abamectin, carbaryl, fenitrothion, methidathion, sulfur, and trichlorfon pesticides on the survival and stage length of larvae and pupae, adult oviposition from treated larvae, and hatched eggs of two Chrysoperla externa (Hagen, 1861) (Neuroptera: Chrysopidae) populations. The compounds were sprayed on glass plates in accordance with the International Organization for Biological Control (IOBC) recommendations. First- and second-instar larvae were exposed to pesticide residues. Carbaryl, fenitrothion, and methidathion caused $100 \%$ mortality of first- and second-instar larvae. Changes in the number of eggs laid by females from first- and second-instar larvae exposed to residues of abamectin and sulfur, or abamectin, sulfur, and trichlorfon, respectively, were not observed. Only abamectin reduced the number of hatched eggs laid by females in Bento Gonçalves from treated first-instar larvae. Sulfur reduced the viability of C. externa eggs in Bento Gonçalves and Vacaria females from treated second-instar larvae, whereas trichlorfon and abamectin reduced the viability of eggs in Vacaria females. In conclusion, carbaryl, fenitrothion and methidathion were harmful to C. externa. Trichlorfon was harmful to first-instar larvae and slightly harmful to second-instar larvae. Abamectin and sulfur were slightly harmful to first-instar larvae and harmless to second-instar larvae.
\end{abstract}

Key words: Green lacewings, insecticides, natural enemies, pest control, side effects.

$\mathrm{S}$ everal species of arthropod pests are associated with the apple (Malus domestica Borkh.) crop in Brazil, especially the oriental fruit moth Grapholita molesta (Busck, 1916), the Brazilian apple leafroller Bonagota salubricola (Meyrick, 1937) (Lepidoptera: Tortricidae), and the South American fruit fly Anastrepha fraterculus (Wiedemann, 1830) (Diptera: Tephritidae), which are key pests and limiting factors to Brazilian pomiculture (Botton et al., 2003; Kovaleski and Ribeiro, 2003; Arioli et al., 2004; Kovaleski, 2004).

These three pests and other phytophagous species on apple trees in Brazil greatly influence the production and marketing of this temperate climate fruit in the domestic market as well as for export. In the domestic market, fruit product quality and residual presence of pesticides used for pest control are factors which can affect marketing

${ }^{1}$ Brazilian Agricultural Research Corporation (EMBRAPA), Embrapa Vegetables, 70359-970, P.O. Box 218, Brasília, DF, Brazil. *Corresponding author (apmoura@cnph.embrapa.br).

${ }^{2}$ Universidade Federal de Lavras, Departamento de Entomologia, 37200-000, P.O. Box 3037, Lavras, Minas Gerais, Brazil (gacarval@ den.ufla.br).

${ }^{3}$ Brazilian Agricultural Research Corporation (EMBRAPA), Embrapa Grape \& Wine, 95700-000, P.O. Box 130, Bento Gonçalves, Rio Grande do Sul, Brazil (marcos@cnpuv.embrapa.br).

Received: 14 June 2011.

Accepted: 16 May 2012. of this fruit. Internationally, in addition to the previously mentioned factors, we can also cite the requirements imposed by consumer markets regarding the restricted transit of plant products from countries with quarantine pest problems (e.g. the fruit fly A. fraterculus) (Moura et al., 2010).

The imposed requirements have forced Brazilian producers to adapt to the integrated fruit production system. This system aims at managing the crop so that plants can express their natural tolerance to pests and diseases. Furthermore, it encourages the preservation of beneficial organisms occurring in the crop, the reduction of pesticide use, greater protection for the producer and consumer health, and the reduction of environmental impact (Kovaleski and Ribeiro, 2003).

One way to reach these goals in Brazilian pomiculture is through integrated pest management strategies, including the protection of natural enemies in the orchards. Chrysoperla externa (Hagen, 1861) (Neuroptera: Chrysopidae) is one of the most important natural enemies in apple orchards (Freitas and Penny, 2001; Carvalho and Souza, 2002; Medina et al., 2003; Athan et al., 2004) and has been reported as an efficient biological control agent of the San Jose scale Quadraspidiotus perniciosus (Comstock, 1881) (Hemiptera: Diaspididae), the apple aphid Aphis citricola van der Goot, 1912 (Hemiptera: 
Aphididae), and the European red spider mite Panonychus ulmi (Koch, 1836) (Acari: Tetranychidae) (Ribeiro and Flores, 2002; Bezerra et al., 2006; Giolo et al., 2009), which are important arthropod pests of apple orchards in southern Brazil.

Therefore, the aim of this study was to evaluate the effects of some pesticides used in Brazil's integrated apple production on first- and second-instar larvae of $C$. externa, subsequent developmental stages of this species, and its reproduction.

\section{MATERIALS AND METHODS}

The bioassays used $C$. externa strains collected in commercial orchards located in Bento Gonçalves

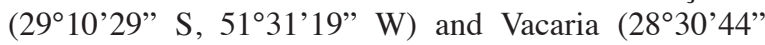
S, 5056'02" W), which are the major apple-producing counties in Rio Grande do Sul, Brazil, and because differentiated tolerance to pesticides between these strains was observed. Rearing was established from the collected insects under controlled conditions at $25 \pm 2{ }^{\circ} \mathrm{C}, 70 \pm 10 \%$ $\mathrm{RH}$, and 12:12 $\mathrm{h}$ photoperiod as described by Carvalho and Souza (2009).

Pesticides. Commercial formulations of abamectin 18 $\mathrm{CE}$ [mixture of at least $80 \%$ avermectin $\mathrm{B}_{1 \mathrm{a}}$ and no more than $20 \%$ avermectin $\mathrm{B}_{1 \mathrm{~b}}$ (Campbell, 1989), $0.02 \mathrm{~g}$ ai $\mathrm{L}^{-1}$ ], carbaryl $480 \mathrm{SC}$ (1-naphthyl methylcarbamate, 1.73 g ai $\left.\mathrm{L}^{-1}\right)$, sulfur $800 \mathrm{WG}\left(4.8 \mathrm{~g}\right.$ ai $\left.\mathrm{L}^{-1}\right)$, fenitrothion 500 EC $(O, O$-dimethyl $O$-4-nitro- $m$-tolyl phosphorothioate, $0.75 \mathrm{~g}$ ai $\left.\mathrm{L}^{-1}\right)$, methidathion $400 \mathrm{EC}$ ( $S$-2,3-dihydro5 -methoxy-2-oxo-1,3,4-thiadiazol-3-ylmethyl $O, O$-dimethyl phosphorodithioate, $4 \mathrm{~g}$ ai $\mathrm{L}^{-1}$ ), and trichlorfon $500 \mathrm{SC}$ (dimethyl (RS)-2,2,2-trichloro-1hydroxyethylphosphonate, $1.5 \mathrm{~g}$ ai $\mathrm{L}^{-1}$ ) pesticides were used in the bioassays with first- and second-instar larvae of $C$. externa. Pesticides and dosages evaluated in this study correspond to commercial recommendations for controlling pests and diseases in Brazil's integrated apple production.Pesticide aqueous solutions were prepared with distilled water. We also used distilled water as a control.

Pesticide aqueous solutions and distilled water were applied on glass plates with a Potter Tower (Burkard Scientific Ltd., Uxbridge, UK) regulated at $\cong 103.42$ $\mathrm{kPa}(\cong 15 \mathrm{psi})$ and ensuring the application of 1.53-1.87 $\mathrm{mg} \mathrm{cm} \mathrm{cm}^{-2}$ in accordance with the methodology suggested by the International Organization for Biological Control (IOBC) (Hassan et al., 1994; Sterk et al., 1999; van de Veire et al., 2002).

\section{Bioassays}

Effects of pesticides on first- and second-instar larvae of $\boldsymbol{C}$. externa. These bioassays used a glass plate $(5 \mathrm{~mm}$, $11.6 \mathrm{~cm} \times 9.6 \mathrm{~cm})$ as a test unit. The tested pesticides were sprayed on glass plates as described above. The glass plates were dried under environmental conditions. Afterwards, the plates were arranged on a table under controlled conditions $\left(25 \pm 2{ }^{\circ} \mathrm{C}, 70 \pm 10 \% \mathrm{RH}\right.$, and $12: 12$ $\mathrm{h}$ photoperiod), and a piece of styrofoam was fixed onto each plate with two rubber bands. A central styrofoam disc (7.5 cm diameter) was cut and a PVC pipe (7.2 $\mathrm{cm}$ diameter $\times 2.0 \mathrm{~cm}$ ) was inserted, thus establishing a contact area $\left(\approx 40.7 \mathrm{~cm}^{2}\right)$ for the insects on the plates containing pesticide residues. The top of each PVC pipe was closed with a fine tulle cloth. The inner walls of the pipes were coated with polytetrafluoroethylene (fluon) to avoid the holding and movement of the larvae on the PVC pipe wall, their escape, and ensure insect contact with the treated surface.

First- and second-instar larvae of C. externa, aged 0 to $24 \mathrm{~h}$ obtained from the rearing, were then singly placed in each arena and fed ad libitum at 3-d intervals with UVkilled eggs of the factitious prey Anagasta kuehniella (Zeller, 1879) (Lepidoptera: Pyralidae). Treatment consisted of thirty first- and second-instar larvae of $C$. externa from each population in the bioassays with first- or second-instar larvae, respectively. Larvae were maintained in the arenas until the pupal stage. Mortality of larvae and pupae were evaluated.

We used a completely randomized experimental design with a $2 \times 7$ (two populations $\times$ seven treatments) factorial scheme for each bioassay (first- or second-instar larvae of C. externa). Treatments were replicated six times, and each plot was made up of five first- or second-instar larvae.

Effects on subsequent stages of $C$. externa of treated larvae. Five days after the pupae appeared, they were transferred one by one to glass tubes $(2.5 \mathrm{~cm}$ diameter $\times 8.5 \mathrm{~cm}$ ) which were closed with a PVC film and kept under controlled conditions $\left(25 \pm 2{ }^{\circ} \mathrm{C}, 70 \pm 10 \% \mathrm{RH}\right.$, and 12:12 $\mathrm{h}$ photoperiod) until the adults emerged. Sex ratio of the emerged adults was evaluated.

Male and female $C$. externa adults of treated firstand second-instar larvae were sexed by looking closely at the ventral surface of the tip of the abdomen with a stereoscopic microscope (40X) as described by Reddy (2002) and Reddy et al. (2004). Males have a small rounded capsule flanked by two small projections, while females have an oval area bounding a longitudinal slit.

A pair of $C$. externa (made up of one male and one female), aged 0 to $24 \mathrm{~h}$, was transferred to a PVC cage (7.5 $\mathrm{cm}$ diameter $\times 8.0 \mathrm{~cm}$ ) covered internally with white filter paper, closed at the top with anorganza cloth, supported on a plastic tray $(40 \mathrm{~cm}$ long $\times 20 \mathrm{~cm}$ wide $\times 10 \mathrm{~cm}$ high $)$, and fed every $3 \mathrm{~d}$ with 1:1 (v/v) brewer's yeast and honey. The cages were kept at $25 \pm 2{ }^{\circ} \mathrm{C}, 70 \pm 10 \% \mathrm{RH}$, and 12:12 $\mathrm{h}$ photoperiod. Evaluations took place twice a day at 12-h intervals until oviposition started.

After oviposition began, and during four consecutive weeks, the number of eggs deposited was counted at 3-d 
intervals. Ninety-six eggs (per treatment) were separated into microtitration plate compartments with a camel hair brush. The plates were closed with a PVC film and kept under controlled conditions until the eggs hatched when egg viability was evaluated.

The bioassay with adults of treated first-instar larvae consisted of a completely randomized experimental design in a $2 \times 3$ (two populations of $C$. externa $\times$ three treatments) factorial scheme. Between three and six replicates were used and the experimental plot was made up of one pair of C.externa. On the other hand, the bioassay with adults of treated second-instar larvae consisted of a completely randomized experimental design in a $2 \times 4$ (two populations of $C$. externa $\times$ four treatments) factorial scheme. Between five and six replicates were used and the experimental plot was made up of one pair of the predator. Eight replicates with an experimental plot made up of 12 eggs were carried out in order to evaluate the effects of the compounds on egg viability.

Pesticide classification in accordance with IOBC. Insect mortality rates of the treated stage until adult emergence were corrected by Abbott's formula (Abbott, 1925). Pesticides were then classified based on the reduction of the beneficial capacity and mortality caused to the predator by Equation [1] proposed by Vogt (1992):

$$
E=100 \%-(100 \%-M \%) \times R_{1} \times R
$$

where $E=$ total effect $(\%) ; M \%=$ corrected mortality as a function of the control (Abbott, 1925); $R_{1}=$ ratio of daily mean number of eggs laid by treated and non-treated females; $R_{2}=$ ratio of mean hatched egg laid by treated and non-treated females.

In accordance with the IOBC recommendations, evaluated pesticides were organized in four toxicological classes (Hassan et al., 1994; Sterk et al., 1999; van de Veire et al., 2002): class $1=$ harmless $(\mathrm{E}<30 \%)$, class 2 $=$ slightly harmful $(30 \% \leq \mathrm{E} \leq 80 \%)$, class $3=$ moderately harmful $(80 \%<\mathrm{E} \leq 99 \%)$, and class $4=$ harmful $(\mathrm{E}>$ $99 \%)$.

Statistical analysis. Data in the bioassays with larvae of C. externa were subjected to a two-way ANOVA; data referring to the number of eggs deposited by female $C$. externa and to the eggs' viability followed a split plot arrangement. The means of the different treatments were compared by the Scott-Knott clustering test (Scott and Knott, 1974) at 5\% significance when the $F$-test was significant with the SAS statistical software (SAS Institute, 2001).

An angular transformation (arcsine $\sqrt{ } \mathrm{x} / 100$ transform) of mortality data from the bioassays with treated first- and second-instar larvae was performed before processing the variance analysis. Data referring to the number of eggs laid per female from first-instar larvae (Vacaria population) were transformed to $\sqrt{ } \mathrm{x}+1$.

\section{RESULTS AND DISCUSSION}

Bioassay with first-instar larvae of $\boldsymbol{C}$. externa. The trichlorfon, carbaryl, fenitrothion, and methidathion pesticides caused $100 \%$ mortality of treated first-instar larvae of $C$. externa in both studied populations (Table 1). Due to the high mortality rates caused by these pesticides, we were unable to evaluate the side effects of the pesticides on other biological parameters of the predator. Reported mortality rates in this study for sulfur and abamectin were $3.3 \%$ and $23.3 \%$ for insects in Bento Gonçalves and 30\% and $50 \%$ for insects inVacaria, respectively. It was also verified that sulfur and abamectin were more harmful to insects inVacaria than in Bento Gonçalves.

Mortality rates caused by trichlorfon, carbaryl, fenitrothion, and methidathion to first-instar larvae of C. externa of both studied populations demonstrate the high toxicity of these pesticides in this developmental stage of the predator, considered the most susceptible of this natural enemy. Studies conducted by Carvalho et al. (2002) and Silva et al. (2005) also evidenced the high toxicity of the organophosphates trichlorfon and chlorpyrifos, respectively, to first-instar larvae of $C$. externa and reported mortality rates of $97.7 \%$ and $100.0 \%$, respectively.

Chlorpyrifos were also shown to be highly harmful to first-instar larvae of C. externa by causing a $100 \%$ mortality rate in a study carried out by Ferreira et al.(2006), who used the same predator populations as in this study. Regarding the lacewing Chrysoperla carnea (Stephens, 1836), Singh and Varma (1986) verified that fenitrothion was highly toxic for first-instar larvae by causing $90 \%$ mortality of

Table 1. Cumulative mortality $(\%)( \pm \mathrm{SE})^{1}$ of Chrysoperla externa of treated first-instar larvae ${ }^{1,2}$ in Bento Gonçalves and Vacaria counties, Rio Grande do Sul, Brazil.

\begin{tabular}{|c|c|c|c|c|c|c|c|c|}
\hline \multirow[b]{2}{*}{ Treatment } & \multicolumn{2}{|c|}{ First instar } & \multicolumn{2}{|c|}{ Second instar } & \multicolumn{2}{|c|}{ Third instar } & \multicolumn{2}{|c|}{ Pupal stage } \\
\hline & BG & VAC & $\mathrm{BG}$ & VAC & BG & VAC & BG & VAC \\
\hline Control & $0.0 \pm 0.00 \mathrm{Cb}$ & $13.3 \pm 4.22 \mathrm{Da}$ & $16.7 \pm 3.33 \mathrm{Da}$ & $16.7 \pm 8.03 \mathrm{Ca}$ & $16.7 \pm 3.33 \mathrm{Ca}$ & $16.7 \pm 8.03 \mathrm{Ca}$ & $16.7 \pm 3.33 \mathrm{Ca}$ & $16.7 \pm 8.03 \mathrm{Ca}$ \\
\hline Trichlorfon & $100.0 \pm 0.00 \mathrm{Aa}$ & $100.0 \pm 0.00 \mathrm{Aa}$ & $100.0 \pm 0.00 \mathrm{Aa}$ & $100.0 \pm 0.00 \mathrm{Aa}$ & $100.0 \pm 0.00 \mathrm{Aa}$ & $100.0 \pm 0.00 \mathrm{Aa}$ & $100.0 \pm 0.00 \mathrm{Aa}$ & $100.0 \pm 0.00 \mathrm{Aa}$ \\
\hline Sulfur & $3.3 \pm 1.67 \mathrm{Cb}$ & $30.0 \pm 4.47 \mathrm{Ca}$ & $36.7 \pm 13.08 \mathrm{Ca}$ & $43.3 \pm 3.33 \mathrm{Ba}$ & $56.7 \pm 15.85 \mathrm{Ba}$ & $50.0 \pm 4.47 \mathrm{Ba}$ & $60.0 \pm 15.49 \mathrm{Ba}$ & $56.7 \pm 3.33 \mathrm{Ba}$ \\
\hline Carbaryl & $100.0 \pm 0.00 \mathrm{Aa}$ & $100.0 \pm 0.00 \mathrm{Aa}$ & $100.0 \pm 0.00 \mathrm{Aa}$ & $100.0 \pm 0.00 \mathrm{Aa}$ & $100.0 \pm 0.00 \mathrm{Aa}$ & $100.0 \pm 0.00 \mathrm{Aa}$ & $100.0 \pm 0.00 \mathrm{Aa}$ & $100.0 \pm 0.00 \mathrm{Aa}$ \\
\hline Fenitrothion & $100.0 \pm 0.00 \mathrm{Aa}$ & $100.0 \pm 0.00 \mathrm{Aa}$ & $100.0 \pm 0.00 \mathrm{Aa}$ & $100.0 \pm 0.00 \mathrm{Aa}$ & $100.0 \pm 0.00 \mathrm{Aa}$ & $100.0 \pm 0.00 \mathrm{Aa}$ & $100.0 \pm 0.00 \mathrm{Aa}$ & $100.0 \pm 0.00 \mathrm{Aa}$ \\
\hline Methidathion & $100.0 \pm 0.00 \mathrm{Aa}$ & $100.0 \pm 0.00 \mathrm{Aa}$ & $100.0 \pm 0.00 \mathrm{Aa}$ & $100.0 \pm 0.00 \mathrm{Aa}$ & $100.0 \pm 0.00 \mathrm{Aa}$ & $100.0 \pm 0.00 \mathrm{Aa}$ & $100.0 \pm 0.00 \mathrm{Aa}$ & $100.0 \pm 0.00 \mathrm{Aa}$ \\
\hline Abamectin & $23.3 \pm 9.55 \mathrm{Bb}$ & $50.0 \pm 8.56 \mathrm{Ba}$ & $56.7 \pm 8.03 \mathrm{Ba}$ & $50.0 \pm 8.56 \mathrm{Ba}$ & $56.7 \pm 8.03 \mathrm{Ba}$ & $50.0 \pm 8.56 \mathrm{Ba}$ & $60.0 \pm 7.30 \mathrm{Ba}$ & $53.3 \pm 6.67 \mathrm{Ba}$ \\
\hline
\end{tabular}

SE: Standard error; BG: Bento Gonçalves; VAC: Vacaria.

${ }^{1}$ Means followed by the same letter, lowercase in rows and uppercase in columns, show no differences accordingto the Scott-Knott test $(\mathrm{P}>0.05)$

${ }^{2}$ Data transformed to $\operatorname{arc} \sin \sqrt{\mathrm{x}} / 100$. 
the tested insects $72 \mathrm{~h}$ after exposure to pesticide residues. In the other developmental stages of C.externa of treated first-instar larvae, sulfur caused accumulated mortality rates of $60.0 \%$ and $56.7 \%$ at the pupalstage to insects in Bento Gonçalves and Vacaria, respectively (Table 1). Accumulated mortality rates reported at the pupal stage for abamectin were $60.0 \%$ and $53.3 \%$ for individuals in Bento Gonçalves and Vacaria, respectively.

These findings for abamectin are similar to those reported by Godoy et al. (2004), who observed approximate accumulated mortality rates of $77 \%$ at the pupal stage of first-instar larvae of $C$. externa exposed to residues of this pesticide. On the other hand, our findings for sulfur are different than those found by Silva et al. (2005), who reported just 5\% mortality of C. externa at the pupal stage of treated first-instar larvae. These differences can be associated with the different pesticide dosages used in the studies, as well as to a possible differentiated exposition of the predator strains occurring in their original habitat. According to Croft (1990), the cited differentiated exposition of the predator strains to sulfur could have caused the selection of more tolerant individuals, thus influencing results obtained under controlled conditions. However, the physiological bases that could explain these differences are not clear.

None of the tested pesticides affected either sex ratio or oviposition capacity (total number of eggs) of $C$. externa of treated first-instar larvae (Table 2). However, abamectin reduced the viability of eggs laid by the emerged adults in the Bento Gonçalves population. For the sex ratio of emerged adults from sulfur-treated first-instar larvae of $C$. externa, our findings support those reported by Silva et al. (2005), who did not verify the effect of the compound on this biological trait of this predator species.

Reduced viability caused by abamectin on eggs laid by emerged adults of treated first-instar larvae reported in this study can be due to the "latent effects" of this pesticide on the predator. According to Croft (1990), latent effects of pesticides are those expressed by a life stage of a natural enemy subsequent to the initially exposed one.

Reduced viability, as observed in eggs laid by adults of C. externa of abamectin-treated first-instar larvae, could be also due to its sublethal effects on this species. According to Croft (1990), sublethal effects are those that alter the population's intrinsic rate of increase, such as fecundity, longevity, and sex ratio of entomophaga. By considering some physiological events of the insects, these effects can be side effects of this pesticide on oogenesis, possibly on trophocytes (sister cells of the oocytes), and are responsible for their nutrition. According to Chapman (1998), the trophocyte malformation or the absorption of contaminated proteins by these cells can result in a lack of nutrients for embryos or changes in embryo development, which lead to the embryo's death. In this way, abamectin must have affected such physiological events and reduced the viability rate.

In view of the accumulated mortality rates caused by the tested pesticides to $C$. externa of treated first-instar larvae in Bento Gonçalves and Vacaria, as well as its effects on reproductive capacity and egg viability (Tables 1 and 2), sulfur and abamectin were classified as slightly harmful (class 2), while trichlorfon, carbaryl, fenitrothion, and methidathion were classified as harmful (class 4) for both of the studied populations (Table 3 ).

Table 3. Effects of six different pesticides on the mortality (\%), oviposition capacity, viability of eggs (\%), total effect (E) (\%), and toxicity classification of Chrysoperla externa of treated first-instar larvae in Bento Gonçalves and Vacaria counties, Rio Grande do Sul, Brazil.

\begin{tabular}{|c|c|c|c|c|c|c|}
\hline \multirow[b]{2}{*}{ Treatment } & \multicolumn{6}{|c|}{ Bento Gonçalves population } \\
\hline & Mortality & $\mathrm{M}^{1}(\%)$ & $\mathrm{R}^{\prime 2}$ & $\mathrm{R}{ }^{\prime 3}(\%)$ & $\begin{array}{c}\text { Total } \\
\text { effect (E) }\end{array}$ & Class $^{4}$ \\
\hline Control & 16.7 & - & 20.6 & 95.8 & - & - \\
\hline Trichlorfon & 100.0 & 100.0 & - & - & 100.0 & 4 \\
\hline Sulfur & 60.0 & 52.0 & 21.1 & 95.2 & 51.1 & 2 \\
\hline Carbaryl & 100.0 & 100.0 & - & - & 100.0 & 4 \\
\hline Fenitrothion & 100.0 & 100.0 & - & - & 100.0 & 4 \\
\hline Methidathion & 100.0 & 100.0 & - & - & 100.0 & 4 \\
\hline \multirow[t]{3}{*}{ Abamectin } & 60.0 & 52.0 & 13.8 & 88.1 & 70.4 & 2 \\
\hline & \multicolumn{6}{|c|}{ Vacaria population } \\
\hline & Mortality & $\mathrm{M}^{1}(\%)$ & $\mathrm{R}^{\prime 2}$ & $\mathrm{R}, 3(\%)$ & $\begin{array}{c}\text { Total } \\
\text { effect (E) }\end{array}$ & Class $^{4}$ \\
\hline Control & 16.7 & - & 15.2 & 92.7 & - & - \\
\hline Trichlorfon & 100.0 & 100.0 & - & - & 100.0 & 4 \\
\hline Sulfur & 56.7 & 48.0 & 19.3 & 96.2 & 31.5 & 2 \\
\hline Carbaryl & 100.0 & 100.0 & - & - & 100.0 & 4 \\
\hline Fenitrothion & 100.0 & 100.0 & - & - & 100.0 & 4 \\
\hline Methidathion & 100.0 & 100.0 & - & - & 100.0 & 4 \\
\hline Abamectin & 53.3 & 43.9 & 11.4 & 96.1 & 56.4 & 2 \\
\hline
\end{tabular}

${ }^{1}$ Chrysoperla externa mortality (\%) adjusted as a function of the control treatment (Abbott, 1925).

${ }^{2}$ Mean egg rate per female per day.

${ }^{3}$ Viability of collected eggs in the 4 -wk period.

${ }^{4}$ Toxicity class proposed by members of the International Organization for Biological Control (IOBC) (Hassan et al., 1994; Sterk et al., 1999; van de Veire et al., 2002) where class $2=$ slightly harmful $(30 \% \leq \mathrm{E} \leq 80 \%)$ and class $4=$ harmful $(\mathrm{E}>99 \%)$.

Table 2. Sex ratio, total number of eggs, and viability (\%) ( \pm SE) of eggs laid by Chrysoperla externa of treated first-instar larvae ${ }^{1}$ in Bento Gonçalves and Vacaria counties, Rio Grande do Sul, Brazil.

\begin{tabular}{|c|c|c|c|c|c|c|}
\hline \multirow[b]{2}{*}{ Treatment } & \multicolumn{2}{|c|}{ Sex ratio ${ }^{(\mathrm{ns})}$} & \multicolumn{2}{|c|}{ Total number of eggs ${ }^{(\mathrm{ns}) 2}$} & \multicolumn{2}{|c|}{ Viability of eggs } \\
\hline & BG & VAC & BG & VAC & BG & VAC \\
\hline Control & $0.5 \pm 0.04$ & $0.6 \pm 0.10$ & $556.4 \pm 36.06$ & $409.2 \pm 83.18$ & $95.8 \pm 0.65 \mathrm{Aa}$ & $92.7 \pm 0.67 \mathrm{Bb}$ \\
\hline Trichlorfon & - & - & - & - & - & - \\
\hline Sulfur & $0.3 \pm 0.11$ & $0.5 \pm 0.13$ & $570.0 \pm 97.03$ & $522.0 \pm 23.15$ & $95.2 \pm 0.95 \mathrm{Aa}$ & $96.2 \pm 0.48 \mathrm{Aa}$ \\
\hline Carbaryl & - & - & - & - & - & - \\
\hline Fenitrothion & - & - & - & - & - & - \\
\hline Methidathion & - & - & - & - & - & - \\
\hline Abamectin & $0.6 \pm 0.16$ & $0.7 \pm 0.11$ & $372.6 \pm 65.20$ & $307.0 \pm 90.90$ & $88.1 \pm 1.23 \mathrm{Bb}$ & $96.1 \pm 0.72 \mathrm{Aa}$ \\
\hline
\end{tabular}

SE: Standard error; BG: Bento Gonçalves; VAC: Vacaria; (-): Not evaluated due to high mortality caused by the pesticide.

${ }^{1}$ Means followed by the same letter, lowercase in rows and uppercase in columns, show no differences according to the Scott-Knott test $(\mathrm{P}>0.05)$.

${ }^{2}$ Data transformed to $\sqrt{ } \mathrm{x}+1 ;{ }^{\text {(ns) }}$ Non significant by F-test $(\mathrm{P}>0.05)$. 
The toxicological classification attributed to abamectin in this study to $C$. externa coincides with that obtained by Godoy et al. (2004); however, it is different from that given by Bueno and Freitas (2004), who verified total effect $(\mathrm{E} \%)$ of this pesticide as being lower than $30 \%$ and classified abamectin as harmless (class 1) to this green lacewing species.

The classification for sulfur in this study also differs from the one obtained by Silva et al. (2005), who classified this pesticide as harmless to C.externa. On the other hand, our classification fortrichlorfon, fenitrothion, and methidathion (class $4=$ harmful) coincides with these authors for chlorpyrifos. The discrepancies found between the classifications reported in this study for the abamectin and sulfur pesticides and those indicated by Bueno and Freitas (2004) and Silva et al. (2005), respectively, can be due to the different pesticide dosages which were lower than those used in this study.

Bioassay with second-instar larvae of $C$. externa. When second-instar larvae of $C$. externa of both studied populations were exposed to pesticide residues, it was verified that carbaryl, fenitrothion, and methidathion were highly toxic for these insects and caused $100 \%$ mortality rates (Table 6). Sulfur caused a 3.3\% mortality rate of the tested insects, but only for insects of the Vacaria population. However, at the pupal stage, the recorded abamectin mortality rate was not significantly different from the control. Trichlorfon caused intermediate mortality to second-instar larvae of $C$. externa. Furthermore, no differences were recorded for mortality rates between the studied populations for each treatment and regardless of the evaluated developmental stage (Table 4).

Results forcarbaryl, fenitrothion, and methidathion reveal the high toxicity of these insecticides to this green lacewing species, thus corroborating the findings reported by Croft (1990) for C.carnea. Besides, the results reported in our study for $C$. externa are similar to those reported for other organophosphates (Carvalho et al., 2002; 2003; Costa et al., 2003; Silva et al., 2005).

Findings reported in this study for abamectin and sulfur are also similar to those obtained by Bueno and Freitas (2004) and by Silva et al. (2005), respectively, who did not find any significant effect of these insecticides on secondinstar larvae of $C$. externa. The sex ratio of emerged $C$. externa adults in all the pesticide treatments was not significantly different from the control (Table 5). It is believed that the lack of effect of sulfur and abamectin on C. externa (mortality and sex ratio) could be related to a higher intrinsic-ness or intolerance of second-instar larvae of this green lacewing to some pesticides; this was also reported by Croft (1990). For the total number of eggs laid by adults of $C$. externa of second-instar larvae treated with trichlorfon, sulfur, and abamectin, there were no significant differences observed among treatments (Table 5). However, sulfur significantly reduced the viability of eggs laid by adults of $C$. externa when applied in second-instar larvae of the Bento Gonçalves population. Trichlorfon, sulfur, and abamectin reduced viability of eggs laid by females of the Vacaria population.

Based on the results of insect mortality and the effects on reproductive capacity, and egg viability (Tables 4 and

Table 4. Cumulative mortality (\%) ( \pm SE) of Chrysoperla externa of treated second-instar larvae ${ }^{1,2,3}$ in Bento Gonçalves (BG) and Vacaria (VAC) counties, Rio Grande do Sul, Brazil.

\begin{tabular}{|c|c|c|c|c|c|c|}
\hline \multirow[b]{2}{*}{ Treatment } & \multicolumn{2}{|c|}{ Second instar } & \multicolumn{2}{|c|}{ Third instar } & \multicolumn{2}{|c|}{ Pupal stage } \\
\hline & BG & VAC & BG & VAC & BG & VAC \\
\hline Control & $0.0 \pm 0.00 \mathrm{C}$ & $0.0 \pm 0.00 \mathrm{C}$ & $0.0 \pm 0.00 \mathrm{C}$ & $0.0 \pm 0.00 \mathrm{D}$ & $0.0 \pm 0.00 \mathrm{C}$ & $3.3 \pm 1.37 \mathrm{C}$ \\
\hline Trichlorfon & $43.3 \pm 16.67 \mathrm{~B}$ & $40.0 \pm 10.33 \mathrm{~B}$ & $53.3 \pm 14.30 \mathrm{~B}$ & $46.7 \pm 9.89 B$ & $53.3 \pm 14.30 \mathrm{~B}$ & $50.0 \pm 6.83 \mathrm{~B}$ \\
\hline Sulfur & $0.0 \pm 0.00 \mathrm{C}$ & $0.0 \pm 0.00 \mathrm{C}$ & $0.0 \pm 0.00 \mathrm{C}$ & $0.0 \pm 0.00 \mathrm{D}$ & $0.0 \pm 0.00 \mathrm{C}$ & $3.3 \pm 1.37 \mathrm{C}$ \\
\hline Carbaryl & $100.0 \pm 0.00 \mathrm{~A}$ & $100.0 \pm 0.00 \mathrm{~A}$ & $100.0 \pm 0.00 \mathrm{~A}$ & $100.0 \pm 0.00 \mathrm{~A}$ & $100.0 \pm 0.00 \mathrm{~A}$ & $100.0 \pm 0.00 \mathrm{~A}$ \\
\hline Fenitrothion & $100.0 \pm 0.00 \mathrm{~A}$ & $100.0 \pm 0.00 \mathrm{~A}$ & $100.0 \pm 0.00 \mathrm{~A}$ & $100.0 \pm 0.00 \mathrm{~A}$ & $100.0 \pm 0.00 \mathrm{~A}$ & $100.0 \pm 0.00 \mathrm{~A}$ \\
\hline Methidathion & $100.0 \pm 0.00 \mathrm{~A}$ & $100.0 \pm 0.00 \mathrm{~A}$ & $100.0 \pm 0.00 \mathrm{~A}$ & $100.0 \pm 0.00 \mathrm{~A}$ & $100.0 \pm 0.00 \mathrm{~A}$ & $100.0 \pm 0.00 \mathrm{~A}$ \\
\hline Abamectin & $6.7 \pm 4.22 \mathrm{C}$ & $13.3 \pm 4.22 \mathrm{C}$ & $10.0 \pm 4.47 \mathrm{C}$ & $16.7 \pm 6.15 \mathrm{C}$ & $10.0 \pm 4.47 \mathrm{C}$ & $16.7 \pm 6.15 \mathrm{C}$ \\
\hline
\end{tabular}

SE: Standard error; BG: Bento Gonçalves; VAC: Vacaria.

${ }^{1}$ Means followed by the same uppercase letters in columns show no differences among them according to Scott-Knott test $(\mathrm{P}>0.05)$.

${ }^{2}$ Non significant differences between the studied populations for each treatment.

${ }^{3}$ Data transformed to arc $\sin \sqrt{ } \mathrm{x} / 100$.

Table 5. Sex ratio, total number of eggs, and viability (\%) ( \pm SE) of eggs laid by Chrysoperla externa of treated second-instar larvae ${ }^{1}$ in Bento Gonçalves and Vacaria counties, Rio Grande do Sul, Brazil.

\begin{tabular}{|c|c|c|c|c|c|c|}
\hline \multirow[b]{2}{*}{ Treatment } & \multicolumn{2}{|c|}{$\operatorname{Sex}_{\text {ratio }}^{(\mathrm{ns})}$} & \multicolumn{2}{|c|}{ Total number of eggs } & \multicolumn{2}{|c|}{ Viability of eggs } \\
\hline & BG & VAC & $\mathrm{BG}$ & VAC & BG & VAC \\
\hline Control & $0.6 \pm 0.05$ & $0.6 \pm 0.08$ & $532.4 \pm 41.78 \mathrm{Aa}$ & $689.6 \pm 34.06 \mathrm{Aa}$ & $93.4 \pm 0.80 \mathrm{Ab}$ & $96.7 \pm 0.74 \mathrm{Aa}$ \\
\hline Trichlorfon & $0.7 \pm 0.10$ & $0.7 \pm 0.08$ & $411.0 \pm 99.57 \mathrm{Ab}$ & $695.7 \pm 71.57 \mathrm{Aa}$ & $91.9 \pm 0.93 \mathrm{Aa}$ & $78.6 \pm 1.47 \mathrm{Cb}$ \\
\hline Sulfur & $0.5 \pm 0.09$ & $0.6 \pm 0.10$ & $534.2 \pm 82.57 \mathrm{Ab}$ & $724.6 \pm 44.30 \mathrm{Aa}$ & $80.2 \pm 1.02 \mathrm{Bb}$ & $92.5 \pm 0.81 \mathrm{Ba}$ \\
\hline Carbaryl & - & - & - & - & - & - \\
\hline Fenitrothion & - & - & - & - & - & - \\
\hline Methidathion & - & - & - & - & - & - \\
\hline Abamectin & $0.6 \pm 0.07$ & $0.6 \pm 0.14$ & $510.1 \pm 43.36 \mathrm{Aa}$ & $736.3 \pm 85.66 \mathrm{Aa}$ & $94.6 \pm 0.91 \mathrm{Aa}$ & $93.2 \pm 0.66 \mathrm{Ba}$ \\
\hline
\end{tabular}

SE: Standard error; BG: Bento Gonçalves; VAC: Vacaria; (-): Not evaluated due to high mortality caused by the pesticide.

${ }^{1}$ Means followed by the same letter, lowercase in rows and uppercase in columns, show no differences according to the Scott-Knott test $(\mathrm{P}>0.05)$

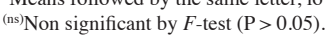


5), sulfur and abamectin were classified as harmless (class 1), whereas trichlorfon was classified as slightly harmful (class 2), and carbaryl, fenitrothion, and methidathion were classified as harmful (class 4) to C. externa of both studied populations (Table 6). The toxicity classification obtained for abamectin in our study corroborates findings reported by Bueno and Freitas (2004) and Godoy et al. (2004), who used the same green lacewing species. The toxicity classification attributed to sulfur in our study was similar to that reported by Silva et al. (2005). Moreover, these authors classified chlorpyrifos as harmful, the same classification reported for fenitrothion and methidathion in the present study.

Table 6. Effects of six different pesticides on the mortality (\%), oviposition capacity, viability of eggs (\%), total effect $(\mathrm{E})(\%)$, and toxicity classification of Chrysoperla externa of treated second-instar larvae in Bento Gonçalves and Vacaria counties, Rio Grande do Sul, Brazil.

\begin{tabular}{lrrrrrr}
\hline & \multicolumn{6}{c}{ Bento Gonçalves population } \\
\cline { 2 - 7 } Treatment & Mortality & $\mathrm{M}^{1}(\%)$ & $\mathrm{R}^{\prime 2}$ & $\mathrm{R}^{\prime \prime 3}(\%)$ & $\begin{array}{c}\text { Total } \\
\text { effect (E) }\end{array}$ & Class $^{4}$ \\
\hline Control & 0.0 & - & 19.7 & 93.4 & - & - \\
Trichlorfon & 53.3 & 53.3 & 15.2 & 91.9 & 64.5 & 2 \\
Sulfur & 0.0 & 0.0 & 19.8 & 80.2 & 13.7 & 1 \\
Carbaryl & 100.0 & 100.0 & - & - & 100.0 & 4 \\
Fenitrothion & 100.0 & 100.0 & - & - & 100.0 & 4 \\
Methidathion & 100.0 & 100.0 & - & - & 100.0 & 4 \\
Abamectin & 10.0 & 10.0 & 18.9 & 94.6 & 12.5 & 1 \\
\hline & & & Vacaria population & & \\
\cline { 2 - 7 } & & & & & Total & \\
Treatment & Mortality & $\mathrm{M}^{1}(\%)$ & $\mathrm{R}{ }^{2}$ & $\mathrm{R}{ }^{\prime 3}(\%)$ & effect (E) & Class ${ }^{4}$ \\
\hline Control & 3.3 & - & 25.5 & 96.7 & - & - \\
Trichlorfon & 50.0 & 48.3 & 25.8 & 78.6 & 57.5 & 2 \\
Sulfur & 3.3 & 0.0 & 26.8 & 92.5 & 0.0 & 1 \\
Carbaryl & 100.0 & 100.0 & - & - & 100.0 & 4 \\
Fenitrothion & 100.0 & 100.0 & - & - & 100.0 & 4 \\
Methidathion & 100.0 & 100.0 & - & - & 100.0 & 4 \\
Abamectin & 16.7 & 13.9 & 27.3 & 93.2 & 11.1 & 1
\end{tabular}

${ }^{1}$ Chrysoperla externa mortality (\%) adjusted as a function of the control treatment (Abbott, 1925).

${ }^{2}$ Mean egg rate per female per day.

${ }^{3}$ Viability of collected eggs in the 4-wk period.

${ }^{4}$ Toxicity class proposed by members of the International Organization for Biological Control (IOBC) (Hassan et al., 1994; Sterk et al., 1999; van de Veire et al., 2002) where class $2=$ slightly harmful $(30 \% \leq \mathrm{E} \leq 80 \%)$ and class $4=$ harmful $(\mathrm{E}>99 \%)$.

\section{CONCLUSIONS}

Sulfur and abamectin were slightly harmful to firstinstar larvae of C. externa, whereas trichlorfon, carbaryl, fenitrothion, and methidathion were harmful to this predator species. On the other hand, sulfur and abamectin were harmless to second-instar larvae of this natural enemy, whereas trichlorfon was slightly harmful, and carbaryl, fenitrothion, and methidathion were harmful. Finally, due to their low toxicity for C.externa, sulfur and abamectin are considered suitable to be used in Integrated Apple Production in Brazil.

\section{ACKNOWLEDGEMENTS}

The authors thank the Brazilian National Council of Scientific and Technological Development (CNPq) for the scholarships it provided.
Efecto residual de los pesticidas utilizados en la producción integrada de manzanas en las larvas de Chrysoperla externa (Hagen) (Neuroptera: Chrysopidae). El cultivo de frutas de clima templado es una actividad económica importante para agricultores del Sur de Brasil. Sin embargo, varias especies de plagas están asociadas al cultivo de la manzana (Malus domestica Borkh.) en Brasil. Los plaguicidas son muy utilizados para su control, y una manera de cambiar esto es la combinación de plaguicidas selectivos e insectos depredadores. Este trabajo tuvo como objetivo evaluar los efectos de abamectina, carbaril, azufre, fenitrotion, metidation, y triclorfon en la supervivencia de larvas y pupas, en la ovipostura de adultos, y en la viabilidad de huevos de dos poblaciones de Chrysoperla externa (Hagen, 1861) (Neuroptera: Chrysopidae). Los tratamientos fueron aplicados en placas de vidrio, y las larvas fueron sometidas a contacto con los productos. Carbaril, fenitrotion, y metidation causaron mortalidad del $100 \%$ de larvas. No se observaron cambios en el número de huevos puestos por hembras procedentes de larvas de primero segundo estadio expuestas a residuos de abamectina y azufre, o abamectina, azufre y triclorfon, respectivamente. Abamectina redujo la viabilidad de huevos puestos por hembras a partir de larvas de primer estadio, procedentes de Bento Gonçalves. Azufre redujo la viabilidad de huevos a partir de larvas de segundo estadio, mientras que abamectina y triclorfon redujeron la viabilidad de huevos puestos por hembras desde Vacaria. Carbaril, fenitrotion y metidation fueron perjudiciales. Triclorfon fue perjudicial para larvas de primer estadio y ligeramente perjudicial para las de segundo. Abamectina y azufre son ligeramente perjudiciales para larvas de primer estadio, sin embargo no ejercen efecto en las de segundo.

Palabras clave: Crisopas verdes, insecticidas, enemigos naturales, control de plagas, efectos secundarios.

\section{LITERATURE CITED}

Abbott, W.S. 1925. A method of computing the effectiveness of an insecticide. Journal of Economic Entomology 18:265-267.

Arioli, C.J., M. Botton, and G.A. Carvalho. 2004. Controle químico da Grapholita molesta (Busck) (Lepidoptera: Tortricidae) na cultura do pessegueiro. Ciência Rural 34:1695-1700.

Athan, R., B. Kaydan, and M.S. Ozgokce. 2004. Feeding activity and life history characteristics of the generalist predator, Chrysoperla externa (Neuroptera: Chrysopidae) at different prey densities. Journal of Pest Science 77:17-21

Bezerra, G.C.D., L.V.C. Santa-Cecília, C.F. Carvalho, and B. Souza. 2006. Aspectos biológicos da fase adulta de Chrysoperla externa (Hagen, 1861) (Neuroptera: Chrysopidae) oriunda de larvas alimentadas com Planococcus citri (Risso, 1813) (Hemiptera: Pseudococcidae). Ciência e Agrotecnologia 30:603-610.

Botton, M., E.R. Hickel, and S.J. Soria. 2003. Pragas. In Fajardo, T.V.M. (ed.) Uvas para processamento. Fitossanidade. Embrapa Informação Tecnológica. Embrapa Uva e Vinho, Brasília, Brazil.

Bueno, A.F., and S. Freitas. 2004. Effect of the insecticides abamectin and lufenuron on eggs and larvae of Chrysoperla externa under laboratory conditions. BioControl 49:277-283. 
Campbell, W.C. (ed.) 1989. Ivermectin and abamectin. SpringerVerlag, New York, USA

Carvalho, G.A., D. Bezerra, B. Souza, and C.F. Carvalho. 2003. Efeitos de inseticidas usados na cultura do algodoeiro sobre Chrysoperla externa (Hagen) (Neuroptera: Chrysopidae). Neotropical Entomology 32:699-706.

Carvalho, G.A., C.F. Carvalho, B. Souza, and J.L.R. Ulhôa. 2002. Seletividade de inseticidas a Chrysoperla externa (Hagen) (Neuroptera: Chrysopidae). Neotropical Entomology 31:615-621.

Carvalho, C.F., and B. Souza. 2002. Potencial de insetos predadores no controle biológico aplicado. In Parra, J.R.P., P.S.M. Botelho, B.S. Corrêa-Ferreira, and J.M.S. Bento (eds.) Controle biológico no Brasil: parasitóides e predadores. Manole, São Paulo, São Paulo, Brazil.

Carvalho, C.F., and B. Souza. 2009. Métodos de criação e produção de crisopídeos. In Bueno, V.H.P. (ed.) Controle biológico de pragas: Produção massal e controle de qualidade. Universidade Federal de Lavras (UFLA), Lavras, Minas Gerais, Brazil.

Chapman, R.F. 1998. The insects: structure and function. Cambridge University Press, Cambridge, UK.

Costa, D.B., B. Souza, G.A. Carvalho, and C.F. Carvalho. 2003. Residual action of insecticides to larvae of Chrysoperla externa (Hagen, 1861) (Neuroptera: Chrysopidae) under greenhouse conditions. Ciência e Agrotecnologia 27:835-839.

Croft, B.A. 1990. Arthropod biological control agents and pesticides. Wiley-Interscience, New York, USA.

Ferreira, A.J., G.A. Carvalho, M. Botton, and O. Lasmar. 2006. Seletividade de inseticidas usados na cultura da macieira a duas populações de Chrysoperla externa (Hagen, 1861) (Neuroptera: Chrysopidae). Ciência Rural 36:378-384.

Freitas, S., and N.D. Penny. 2001. The green lacewings (Neuroptera: Chrysopidae) of Brazilian agro-ecosystems. Proceedings of the California Academy of Sciences 52:245-395.

Giolo, F.P., P. Medina, A.D. Grützmacher, and E. Viñuela. 2009. Effects of pesticides commonly used in peach orchards in Brazil on predatory lacewing Chrysoperla carnea under laboratory conditions. BioControl 54:625-635.

Godoy, M.S., G.A. Carvalho, J.C. Moraes, M.M. Goussain Jr., A.A. Morais, and L.V. Cosme. 2004. Seletividade de inseticidas utilizados na cultura dos citros para ovos e larvas de Chrysoperla externa (Hagen) (Neuroptera: Chrysopidae). Neotropical Entomology 33:639-646.

Hassan, S.A., F. Bigler, H. Bogenschütz, E. Boller, J. Brun, J.N.M. Calis, et al. 1994. Results of the sixth joint pesticide testing programme of the IOBC/WPRS-Working Group "Pesticides and Beneficial Organisms". Entomophaga 39:107-119.

Kovaleski, A. 2004. Pragas. In Nachtigall, G.R. (ed.) Frutas do Brasil: maçã - produção. Embrapa Uva e Vinho, Bento Gonçalves, Rio Grande do Sul, Brazil.

Kovaleski,A., and L.G. Ribeiro. 2003. Manejo de pragas na produção integrada de maçã. In Protas, J.F.S., and R.M.V. Sanhueza (eds.)
Produção integrada de frutas: o caso da maçã no Brasil. Embrapa Uva e Vinho, Bento Gonçalves, Rio Grande do Sul, Brazil.

Medina, P., G. Smagghe, F. Budia, L. Tirry, and E. Viñuela. 2003. Toxicity and absorption of azadirachtin, diflubenzuron, pyriproxyfen and tebufenozide after direct spray in predatory larvae of Chrysoperlacarnea (Stephens) (Neuroptera: Chrysopidae). Environmental Entomology 32:196-203.

Moura, A.P., G.A. Carvalho, V.F. Moscardini, O. Lasmar, D.T. Rezende, and M.C. Marques. 2010. Selectivity of pesticides used in integrated apple production to the lacewings, Chrysoperla externa. Journal of Insect Science 10(121):1-20.

Reddy, G.V.P. 2002. Plant volatiles mediate orientation and plant preference by the predator Chrysoperla carnea Stephens (Neuroptera: Chrysopidae). Biological Control 25:49-55.

Reddy, G.V.P., E. Tabone, and M.T. Smith. 2004. Mediation of host selection and oviposition behavior in the diamondback moth Plutella xylostella and its predator Chrysoperla carnea by chemical cues from cole crops. Biological Control 29:270-277.

Ribeiro, L.G., and E.H. Flores. 2002. Pulgão-verde: Aphis citricola Van der Goot (Homoptera: Aphididae). In EPAGRI. A cultura da macieira. EPAGRI, Florianópolis, Santa Catarina, Brazil.

SAS Institute. 2001. SAS/STAT User's guide. SAS Institute, Cary, North Carolina, USA.

Scott, A.J., and M.A. Knott. 1974. A cluster analysis method for grouping means in the analysis of variance. Biometrics 30:507512.

Silva, R.A., G.A. Carvalho, C.F. Carvalho, P.R. Reis, A.M.A.R. Pereira, and L.V. Cosme. 2005. Toxicidade de produtos fitossanitários utilizados na cultura do cafeeiro a larvas de Chrysoperla externa (Hagen) (Neuroptera: Chrysopidae) e efeitos sobre as fases subseqüentes do predador. Neotropical Entomology 34:951-959.

Singh, P.P., and G.C. Varma. 1986. Comparative toxicities of some insecticides to Chrysoperla carnea (Chrysopidae: Neuroptera) and Trichogramma brasiliensis (Trichogrammatidae: Hymenoptera), two arthropod natural enemies of cotton pests. Agriculture, Ecosystems and Environment 15:23-30.

Sterk, G., S.A. Hassan, M. Baillod, F. Bakker, F. Bigler, S. Blümel, et al. 1999. Results of the seventh joint pesticide testing programme carried out by the IOBC/WPRS-Working Group 'Pesticides and Beneficial Organisms'. BioControl 44:99-117.

van de Veire, M., G. Sterk, M. van der Staaij, P.M.J. Ramakers, and L. Tirry. 2002. Sequential testing scheme for the assessment of the side-effects of plant protection products on the predatory bug Orius laevigatus. BioControl 47:101-113.

Vogt, H. 1992. Untersuchugen zu Nebenwirkungen von Insektiziden und Acariziden auf Chrysoperla carnea (Stephens) (Neuroptera: Chrysopidae). Mededelingen van de Faculteit Landbouwwtenschappen Reijksuniversiteit te Gent 57:559-567. 